\title{
From Zoonosis to Zoopolis
}

\author{
Charlotte E. Blattner \\ Senior researcher and lecturer \\ Institute for Public Law, University of Bern, Switzerland \\ ORCID-Id: https://orcid.org/0000-0003-3530-4330
}

Cita recomendada. BLATTNER, C.E., From Zoonosis to Zoopolis, dA. Derecho Animal (Forum of Animal Law Studies) 11/4 (2020). - DOI https://doi.org/10.5565/rev/da.524

Acknowledgements: I'd like to extend my thanks to Professor Giménez-Candela and everyone at UAB, the International Center for Animal Law and Policy, and Derecho Animal (dA) for organizing Webinar Series "Coronavirus and Animals. The human-animal relationship in pandemic society", which took place from 22 June to 15 July 2020. My gratitude is owed to Kathrin Herrmann, Tobias Sennhauser, and Lukas Schaub for their helpful comments on an earlier draft of this article. I'd also like to thank the two anonymous reviewers for their constructive feedback, which was helped me refine and strengthen my arguments.

\begin{abstract}
Within just a few weeks, COVID-19 has caused unprecedented lockdowns, the extensive use of emergency powers, shifts in how and who makes decisions, and unforeseen consequences for marginalized and newly marginalized individuals. Political leaders and journalists were quick to blame animals, such as bats and pangolins, as the ones "responsible" for this crisis. These accusations have led to animals being stigmatized globally; in some places, they were burned or otherwise killed by the hundreds. Framing animals as the scapegoats of the Corona crisis, however, is neither useful nor justified. Ultimately, it isn't animals themselves, but the way in which we treat them that is the true cause of the pandemic. For the first time in history, experts from diverse fields such as has epidemiology, biology, chemistry, physics, and public health have called for a fundamental change in our relationships with animals. However, they do not sufficiently address what this change and our relationships with animals should look like in the future. Drawing on the recent "political turn" in animal ethics, this paper argues that COVID-19 prompts us to begin working to establish a Zoopolis - a shared interspecies society between humans and domesticated animals, and the recognition of wild animals as sovereigns. In doing so, the paper discusses linkages between pandemics and factory farming, structural similarities between human and animal oppression, and opportunities to consider animals in determining the public good, and to work toward a shared interspecies society.
\end{abstract}

Keywords: interspecies society; animal farming; pandemic; COVID-19; Corona crisis; wildlife protection; bats; pangolins; zoonosis; CAFO.

\section{Resumen - De Zoonosis a Zoopolis}

En tan solo unas pocas semanas, el COVID-19 ha causado bloqueos sin precedentes, el uso extensivo de poderes de emergencia, cambios en cómo y quién toma decisiones y consecuencias imprevistas para las personas marginadas y recientemente marginadas. Los líderes políticos y periodistas se apresuraron a culpar a los animales, como murciélagos y pangolines, como los "responsables" de esta crisis. Estas acusaciones han llevado a que los animales sean estigmatizados a nivel mundial; en algunos lugares, fueron quemados o 
asesinados por cientos. Sin embargo, enmarcar a los animales como chivos expiatorios de la crisis del Corona no es útil ni está justificado. En última instancia, no son los animales en sí mismos, sino la forma en que los tratamos, la verdadera causa de la pandemia. Por primera vez en la historia, expertos de diversos campos como la epidemiología, la biología, la química, la física y la salud pública han pedido un cambio fundamental en nuestras relaciones con los animales. Sin embargo, no abordan suficientemente cómo deberían ser este cambio y nuestras relaciones con los animales en el futuro. Basándose en el reciente "giro político" en la ética animal, este documento sostiene que el COVID-19 nos impulsa a comenzar a trabajar para establecer una Zoopolis, una sociedad interespecie compartida entre humanos y animales domésticos, y el reconocimiento de los animales salvajes como soberanos. Al hacerlo, el documento analiza los vínculos entre las pandemias y la agricultura industrial, las similitudes estructurales entre la opresión humana y animal y las oportunidades para considerar a los animales de cara a determinar el bien público y trabajar hacia una sociedad interespecie compartida.

Palabras clave: sociedad interespecie; producción ganadera; pandemia; COVID-19; crisis del Corona; protección de la vida silvestre; murciélagos; pangolines; zoonosis; CAFO.

\section{Introduction}

Within just a few weeks, COVID-19 has caused unprecedented lockdowns, led to the extensive use of emergency powers, shifts in how and who makes decisions, and unforeseen consequences for marginalized and newly marginalized individuals. Political leaders and journalists were quick to blame animals, such as bats and pangolins, as the ones "responsible" for this crisis. As a consequence, these animals were stigmatized globally; in some places, they were burned or otherwise killed by the hundreds. Framing animals as the scapegoats of the Corona crisis, however, is neither useful nor justified. Ultimately, it isn't animals themselves, but the way in which we treat them that is the true cause of the pandemic. This paper argues that the Corona crisis is a wake-up call to reconsider, reframe, and repurpose human-animal relationships, and sketches reasonable scenarios for the future.

I begin by mapping the emergence of COVID-19 and its vast epidemiological and socio-economic consequences around the world, leading to quick and hasty judgments about animals as drivers of the pandemic. While it is true, as the next section argues, that the most widespread and dominant interactions between humans and wild animals (such as through habitat destruction and invasion, sale, experimentation, and consumption), and humans and domesticated animals (notably through factory farming) carry significant risks for the emergence and transmission of pandemics, and for global health, more generally, blaming animals is unjustified. The crux, ultimately, lies in how we treat them.

Going forward, we have two options: sticking to the status quo and accepting pandemics as "our constant companions" for the future, or seizing this crisis as a momentum for change. For the first time in history, as I then show, COVID-19 has led to a concerted effort of experts from diverse fields such as has epidemiology, biology, chemistry, physics, and public health to call for a fundamental change in our relationships with animals - not just locally, but globally. What this change and our relationships with animals should look like in the future, however, is not sufficiently addressed by them. This is where long-held debates in animal ethics and animal studies, more broadly, come into play, which I discuss next. Drawing on the recent "political turn" in animal ethics, this paper argues that COVID-19 prompts us to begin working to establish a Zoopolis - a shared interspecies society between humans and domesticated animals, and the recognition of wild animals as sovereigns. This paper does not offer a solid proposal detailing all the changes in legal, social, political, and economic structures needed to achieve a Zoopolis. Instead, it shows that a Zoopolis can become a concrete political and legal undertaking at this significant moment of rupture that the Corona crisis represents. Incorporating animal agency into this proposal, as I argue in closing, is critical to its success.

\section{On Pandemics and their Emergence}

Like a scourge out of nowhere, in early 2020, COVID-19 has taken mankind by surprise since and apparently brought it to its knees, within just a few weeks. That an epidemic would arise, escalate into a pandemic and cause a global health crisis was unthinkable for many. Much less did we expect that two-thirds of the world's population would be banished to their own four walls, that their consumption would be 
drastically curtailed, ${ }^{1}$ that airtraffic came to a standstill, ${ }^{2}$ that the world's strongest public health systems would collapse, ${ }^{3}$ parliamentary sessions would be broken off, ${ }^{4}$ extensive emergency powers would be claimed, ${ }^{5}$ borders would be closed, ${ }^{6}$ the global labour market would come to a standstill, ${ }^{7}$ and one of the biggest recessions would follow. ${ }^{8}$ COVID-19, also known as the Coronavirus, and its apocalyptic effects, in short, is "the stuff movies are made of."

As these events arose, the world was swiftly searching for culprits. Headlines like "the pangolin is to blame" or "bats are responsible for the spread of COVID-19"10 spread like a wildfire. Political leaders, too, were quick to blame animals as the ones "responsible for this crisis." ${ }^{11}$ As a consequence, these animals were stigmatized globally; in some places, they were burned or otherwise killed by the hundreds. In China, residents asked that hibernating bats in or near their homes be destroyed. ${ }^{12}$ In Indonesia, hundreds of fruit bats were confiscated by the authorities and burned in their cages. ${ }^{13}$ In North-Western Peru, 300 bats were burned in their caves because local residents mistakenly believed that the animals had transmitted the Coronavirus, which was claiming its first human lives in Peru at the time. Similarly, residents in San Francisco asked for information on how to catch and kill bats to stop the spread of the virus. ${ }^{14}$

However, denouncing individual animals - be it the bat or the pangolin - as scapegoats for the Corona crisis is neither useful nor justified. Ultimately, it is not the bats or pangolins that are the cause of the pandemic, but the way we treat them. ${ }^{15}$ This might seem unnecessarily pedantic to some since in either scenario, bats and pangolins are involved. However, allocating responsibility correctly is needed in order to find out how to contain the spread of COVID-19, in order to find a vaccine, and, not least, to prevent the outbreak of future pandemics. In addition, the question of blame (and answers thereto) is decisive in determining the existence and the kinds of relationships between us and other animals going forward. ${ }^{16}$ For example, in the structurally similar debate about the future of farmed animals (and our relations with them) in a zero-emission climate, the question of whether cows are to be blamed for global warming is equally of importance. ${ }^{17}$

\footnotetext{
${ }^{1}$ KAPNER, S., Coronavirus Has Shut Stores, and Retailers Are Running Out of Time. The Wall Street Journal, 8 April 2020.

2 SLOTNIK, D., Coronavirus Demolished Air Travel around the Globe. Business Insider, 22 April 2020.

${ }^{3}$ PILLING, D., Coronavirus and the Collapse of Global Public Health. Financial Times, 12 March 2020.

${ }^{4}$ Parliamentary shutdowns took place around the globe, including Australia, Switzerland, the U.K. For a country compilation of all responses, see INTER-PARLIAMENTARY UNION, Country Compilation of Parliamentary Responses to the Pandemic. Webpage: https://www.ipu.org/country-compilation-parliamentary-responses-pandemic [Retrieved 7 December 2020]. Similarly, elections were delayed around the globe. See, e.g., for New Zealand, CAVE, D., New Zealand Election Delayed Amid New Coronavirus Outbreak. New York Times, 17 April 2020.

${ }^{5}$ See, e.g., GROSS, O., Emergency Powers in the Time of Coronavirus... and Beyond. Just Security, 8 May 2020, arguing that "we must be especially vigilant to ensure that the extraordinary, allegedly temporary, measures taken to protect us today, are not turned into measures of repression tomorrow" (ibid.). See for an argument that the use of emergency provisions during the COVID-19 pandemic is not an exception, BJØRNSKOV, C. - VOIGT, S., This Time is Different? - On the Use of Emergency Measures During the Corona Pandemic. ILE Working Paper Series No. 36, University of Hamburg, Institute of Law and Economics (ILE), Hamburg. ${ }^{6}$ SALCEDO, A. - YAR, S. - CHERELUS, G., Coronavirus Travel Restrictions, Across the Globe. The New York Times, 16 July 2020.

${ }^{7}$ On the consequences of the pandemic on different sectors of the economy, in the form of job and income losses or significantly modified working conditions, see European Parliamentary Research Service EPRS, Coronavirus and the World of Work. Webpage: https://www.europarl.europa.eu/RegData/etudes/BRIE/2020/649395/EPRS_BRI(2020)649395_EN.pdf [Retrieved 7 December 2020]. See for a broader macro-economic analysis, BOISSAY, F. - RUNGCHAROENKITKUL, P., Macroeconomic Effects of COVID-19: An Early Review. BIS-Bulletin, No. 7, 17 April 2020.

${ }^{8}$ Global economies are expected to recover from the recession by late 2022. For a useful analysis of how this recession compares to other ones, see BOSKIN, M.J., How Does the COVID Recession Compare? World Economic Forum, 28 August 2020.

${ }^{9}$ EVANS, M., Plight of the Pangolin: Once Coveted, Now Feared because of Coronavirus. CNN, 14 June 2020.

${ }^{10}$ DALTON, J., Coronavirus: Exterminating Bats Blamed for Spreading Covid-19 Would Increase Risk of Further Diseases, Warn Experts. The Independent, 19 April 2020.

${ }^{11}$ See for a critical note on how useless this blame-game is, FLINDERS, M., Coronavirus Blame Games - Who really Benefits? The Conservation, 3 April 2020.

12 DALTON, supra note 10.

${ }^{13}$ This was done in Surakarta by the Natural Resources Conservation Center (BKSDA) of Central Java Province, Indonesia; the bats were confiscated from traders at Depok Market: DAILYMOTION, Hundreds of Bats Burned in Indonesia in Bid to Prevent Coronavirus Spread. 1 March 2020.

${ }^{14}$ IRMER, J., Jagd auf Fledermäuse und Flughunde: Die Sündenböcke der Pandemie bezahlen mit dem Leben. NZZ am Sonntag, 4. April 2020.

${ }^{15}$ See for a thorough analysis of 139 instances where an animal virus has spread to humans showing that these outbreaks are a human problem with a human cause: HITCHENS, P. - Johnson, C., Don't Blame the Pangolin (Or Any Other Animals) for COVID-19. Pursuit, 8 April 2020.

${ }^{16}$ More on this below, in the section "Pandemics Can Be Prevented: Our Relations with Animals Will Be Decisive."

${ }^{17}$ Also in this case, the problem is not the animals themselves but our treatment of them: PROBYN-RAPSEY, F.- DONALDSON, S. - IOANNIDES, G. - LEA, T. - MARSH, K., A Sustainable Campus: The Sydney Declaration on Interspecies Sustainability. Animal Studies Journal, 5/1 (2015), 110-151, 137.
} 
In the case of Corona, scientists found viruses very similar to COVID-19 in Chinese horseshoe bats. ${ }^{18}$ Normally, these viruses remain in the body of the bats, which in turn remain within their ecosystems without harming humans. ${ }^{19}$ The risk of inter-species transmission only arises when humans enter the habitats of bats, use them for medical or nutritional purposes or bring them into contact with other animals, which in turn act as intermediate hosts. ${ }^{20}$ This is probably what happened at the Wuhan wet market in China, where, as experts assume, COVID-19 broke out late last year. When bats are brought into stressful situations, such as when they are being hunted or sold alive, they react with symptoms similar to a cold in humans. Their bodies produce viruses, which settle in saliva, urine, and faeces and are then presumably transmitted to Malayan pangolins, which were also sold on the market in Wuhan. ${ }^{21}$ If we then get too close to these animals, which likely happened at a local wet market in Wuhan, the outbreak of a zoonosis is the logical consequence. ${ }^{22}$ If we add global production and supply chains and increased cross-border traffic to this, an epidemic, i.e., a locally or regionally infectious disease, can easily grow into a pandemic, i.e., an infectious disease that threatens a large part of the world's population, in just a few days and - as new research shows - sometimes even just a few hours. ${ }^{23}$

\section{Be it Domesticated Animals or Wild Animals: The Crux Lies in how We Treat Them}

COVID-19 is by no means an outlier. Think of zoonoses like the "Severe Acute Respiratory Syndrome" (SARS), which probably originated in 2003; the "Middle-East Respiratory Syndrome" (MERS), which was discovered in 2012, and avian influenza, such as the H5N1 virus, which has become a common outbreak in poultry production since 1997. In these cases, too, it is not camels, dromedaries, or hens that can or should be blamed for the emergence and spread of zoonoses. It isn't animals themselves, but the way in which we treat them that is the true cause of the pandemic. ${ }^{24}$ In the case of wild animals, we invade their habitats, pack them up with conspecifics, or other wild animals in a very small space, offer them for sale, experiment on them, eat them, or use them as artefacts or trophies. ${ }^{25}$

However, these problems also occur in intensive livestock farming. Animals that are used for agricultural purposes are bred for to increase body mass, improved for maximum performance and kept side by side, under each other and on top of each other for weeks, sometimes even years. ${ }^{26}$ This is the case not just in large agricultural states like the US, where CAFOs emerged, ${ }^{27}$ but even in those countries that are rated to have some of the best protections in the world. The Animal Protection Index, a ranking system established by the NGO World Animal Protection (WAP), ranks 50 countries around the world according to their animal welfare policy and legislation. ${ }^{28}$ It gives Switzerland a "B" in the range from As to Gs, with B being the highest rank yet accorded to states. ${ }^{29}$ This is because Switzerland recognizes animal sentience and prohibits

\footnotetext{
${ }^{18}$ Generally speaking, bats are considered to be major hosts for alphacoronaviruses and betacoronaviruses, due to their extremely complex and highly-developed immune system: DREXLER, J.F. - CORMAN, V.M. - DROSTEN, C., Ecology, Evolution and Classification of Bat Coronaviruses in the Aftermath of SARS. Antiviral Research, 101 (2014), 45-56.

${ }^{19}$ Bats have an increased metabolism and higher body temperatures than most mammals, which is especially useful during flight and might have enhanced their immune-system, from an evolutionary point of view. This, as experts suspect, is a highly effective "virusresistance strategy": O'SHEA, T.J. - CRYAN, P.M. - ANDREW, A. - CUNNINGHAM, A.A. - FOOKS, A.R. - HAYMAN, D.T.S. - LUIS, A.D. - PEEL, A.J. - LOWRIGHT, R.K. - WOOD, J.L.N., Bat Flight and Zoonotic Viruses. Emerging Infectious Diseases, 20 (2014) 741-745.

${ }^{20}$ As Afelt et al. argue: "The main element for the emergence of an infectious disease is the contact. With no contact, there is no possibility for a virus to cross the species barrier." (AFELT, A. - DEVAUX, C. - SERRA-COBO, J. - FRUTOS, R., Bats, Bat-Borne Viruses, and Environmental Changes. IntechOpen, (2018), 113-132, 123. DOI: 10.5772/intechopen.74377).

${ }^{21}$ JABR, F., How Humanity Unleashed a Flood of New Diseases. The New York Times, 25 June 2020.

22 AFELT ET AL., supra note 20, at 116. See for an in-depth analysis of contact as a driving force of zoonoses, and trade and globalization as its facilitators, NEWMAN, S.H. - FIELD, H. - EPSTEIN, J.- DE JONG, C. (eds), Investigating the Role of Bats in Emerging Zoonoses: Balancing Ecology, Conservation and Public Health Interest. FAO Animal Production and Health Manual No. 12. Rome (2011). Webpage: http://www.fao.org/3/a-i2407e.pdf [Retrieved 7 December 2020].

${ }^{23}$ According to the newest Global Risks Report of the World Economic Forum, an «outbreak can move from a remote village to cities around the world in less than 36 hours» (World Economic Forum, Global Risks Report. 14 ${ }^{\text {th }}$ ed. 2019, 46. Webpage: http://www3.weforum.org/docs/WEF_Global_Risks_Report_2019.pdf [Retrieved 7 December 2020].

${ }^{24}$ See for an in-depth analysis, NEWMAN ET AL., supra note 22; AFELT ET AL., supra note 20.

${ }^{25}$ AFELT ET AL., supra note 20, at 116.

${ }^{26}$ One of the earliest analysis of CAFOs was offered by MASON, J. - SINGER, P., Animal Factories (New York 1980, revised 1990). See also MASON, J. - FINELLI, M., Brave New Farm? In In Defense of Animals: The Second Wave (Malden MA and Oxford, UK, 2006) 104-122.

${ }^{27}$ Ibid.

28 World Animal Protection (WAP), Animal Protection Index. Webpage: https://api.worldanimalprotection.org/ [Retrieved 7 December 2020].

${ }^{29}$ World Animal Protection (WAP), Switzerland. Webpage: https://api.worldanimalprotection.org/country/switzerland [Retrieved 7
} 
animal suffering, has established animal welfare legislation in place, directs government bodies to abide by animal protection, and supports international animal welfare standards.$^{30}$ However even in Switzerland, on one farm alone, one can keep up to 300 calves, 2,000 pigs, 18,000 laying hens, or 27,000 broilers. ${ }^{31}$ On the factory farm, animals live a life in their own and others' excrements and they are muted by an environment where dead young animals are thrown into the garbage can. ${ }^{32}$ Each and every one of them is on the brink of death. Broiler producers, for example, build $30-40 \%$ mortality into their profitability calculations. ${ }^{33}$ Those animals who hold out until slaughter have little or no opportunity to move or exercise their needs during their short lives. Extreme confinement causes them to suffer from chronic, production-related diseases, including liver abscesses, mastitis, ascites, lameness, and uterine prolapse ${ }^{34}$ which is often accompanied by feelings of aggression, frustration, mourning, and lethal stress syndromes. ${ }^{35}$

It is precisely these concentrated factory farms that operate as breeding grounds for novel pathogens: if animals are crammed together in a confined space, this causes them to suffer permanent stress, which weakens their immune system and increases the risk of viral transmission..$^{36}$ The more generations of viruses are present in one area - which is the case in industrial agriculture - the more likely they are to undergo mutation. ${ }^{37}$ These are optimal conditions for viruses to develop human-specific characteristics due to contact with humans, and to soon grow into a pandemic. ${ }^{38}$ According to a new report by the Farm Animal Investment Risk and Return (FAIRR) initiative, as many as $70 \%$ of the world's largest listed meat, fish, and dairy companies are demonstrably exposed to a "high risk" of promoting future zoonotic pandemics. ${ }^{39}$

The steady increase in industrial livestock farming poses a global risk to public health in other ways, notably through its high contribution to antimicrobial resistance. In all regions of the world, bacteria, parasites, viruses, and fungi are becoming increasingly resistant to antimicrobial drugs, largely due to the use of antibiotics in the livestock industry (such as penicillin and tetracyclines).$^{40}$ And this is true regardless of whether antibiotics are used for growth promotion or simply to keep animals alive in adverse conditions. ${ }^{41}$ Due to the ever-increasing demand for animal products, the total consumption of antibiotics in animal feed production is expected to increase by almost $70 \%$ between 2010 and $2030 .{ }^{42}$ Today, 700 ' 000 people die from

\footnotetext{
December 2020].

30 Ibid.

${ }^{31}$ Verordnung über Höchstbestände in der Fleisch- und Eierproduktion (Höchstbestandesverordnung, HBV). SR 916.344. 23 October 2013. Art. 2 para. 1 (Switz.). Among other things, it is also permitted to keep up to 17 chickens per square metre and up to ten pigs weighing $100 \mathrm{~kg}$ on an area identical in size with a parking lot. In addition, the tethering of dairy cows is generally permitted in Switzerland.

${ }^{32}$ Footage showing that this is also the case in Switzerland, the country with allegedly one of the best animal laws in the world, is provided by Tier im Fokus (TIF), Arme Schweine. Webpage: https://arme-schweine.ch/ [Retrieved 7 December 2020].

${ }^{33}$ MATHENY, G. - LEAHY, C., Farm-Animal Welfare, Legislation and Trade. L. \& Contemp. Probs., 70 (2007), 325, 329; MASON - SINGER, supra note 26, at 25. On increasing mortality of farmed animals during production, see European Commission, Communication from the Commission to the Council and the European Parliament on Animal Welfare Legislation on Farmed Animals in Third Countries and the Implications for the EU. COM(2002) 626 final (18 November 2002), at 9.

${ }^{34}$ MATHENY - LEAHY, supra note 33, at 328.

${ }^{35}$ URALDE, J., Congress' Failure to Enact Animal Welfare Legislation for the Rearing of Farm Animals: What Is Truly at Stake? U. Miami Bus. L. Rev., 9 (2001), 193, 197; MASON - SINGER, supra note 26, at 22.

${ }^{36}$ MUKERJI, N. - MANNINO, A., Covid-19: Was in der Krise zählt (Stuttgart 2020), 93-94.

${ }^{37}$ WALLACE, R.G., Breeding Influenza: The Political Virology of Offshore Farming. Antipode, $41 / 5$ (2009), 916-951; KARESH, W.B. - DOBSON, A. - LLOYD-SMITH, J.O. - LUBROTH, J. - DIXON, M.A. - BENNETT, M. ALDRICH, S.- HARRINGTON, T. - FORMENTY, P. - LOH, E.H. - MACHALABA, C.C. - JASON, M. - HEYMANN, D.L., The Ecology of Zoonoses: Natural and Unnatural Histories. The Lancet, 380 (2012), 1936-1945; KAPAN, D.D. - BENNETT, S.N. - ELLIS, B.N. - FOX, J. - LEWIS, N.D. - SPENCER, J.H., SAKSENA, S. - WILCOX B.A., Avian Influenza (H5N1) and the Evolutionary and Social Ecology of Infectious Disease Emergence. EcoHealth, 3 (2006), 187-194. For an in-depth analysis of factory farms as drivers of zoonoses, see WALLACE, R., Big Farms Make Big Flu: Dispatches on Infectious Disease, Agribusiness, and the Nature of Science (New York 2016).

${ }^{38}$ Ibid.

${ }^{39}$ Farm Animal Investment Risk and Return (FAIRR), An Industry Infected: Animal Agriculture in a post-COVID World (2020), at 2. Webpage: https://www.fairr.org/article/industry-infected/ [Retrieved 7 December 2020].

${ }^{40}$ DRUCKENFIELD, J., Antibiotic Resistance Due to Modern Agricultural Practices: An Ethical Perspective. Journal of Agricultural and Environmental Ethics, 26 (2013), 333-350. The first large-scale assessment (covering 228 countries) of the use of antibiotics in the livestock industry was carried out in 2015: VAN BOECKEL, T.P. - BROWER, C. - GILBERT, M. - GRENFELL, B.T. - LEVIN, S.A. - ROBINSON, T.P. - TEILLANT, A. - LAXMINARAYAN, R., Global Trends in Antimicrobial Use in Food Animals, PNAS, $112 / 18(2015), 5649-5654$.

${ }^{41}$ In Switzerland, for example, the use of antibiotics for growth is prohibited. Broadly speaking, the country thus follows an "organic model." As most animals are born into adverse conditions and separated from their mothers in the first few hours after birth, they're immunologically weakened and, consequently, often develop diseases that have to be treated by antibiotics. This is the case, for example, in calves, many of whom end up suffering from respiratory diseases: BEER, G. - DOHERR, M.G. - BÄHLER, C. MEYLAN, M., Antibiotikaeinsatz in der Schweizer Kälbermast. SAT / ASMV, 1 (2015), 55-57. DOI 10.17236/sat00005.

${ }^{42}$ SNEERINGER, S. - MACDONALD, J. - KEY, N. - MCBRIDE, W. - MATHEWS, K., Economics of Antibiotic Use in US
} 
antimicrobial-resistant diseases each year. And should the current trend continue, diseases caused by drugresistant microbes are expected kill up to 9.5 million people per year by 2050 - which is more than current cancer-deaths. $^{43}$

\section{Science Demands Change - For the Sake of Public Health and the Environment}

The global risks of antibiotic resistance have long been known. Today, we also know that the COVID19 pandemic scenario was already known to public officials in $2013^{44}$ and that its reappearance and the outbreak of future pandemics are very likely. ${ }^{45}$ In other words, pandemics will increase in frequency and spread further unless and only if we are willing to fundamentally change how we treat animals. Science, at least, is in agreement on this. In May 2020, over 120 scientists from Central Europe addressed the public in an open letter. ${ }^{46}$ The research group from the fields of epidemiology, biology, and chemistry - including Nobel Prize winner Jacques Dubochet from the University of Lausanne - agrees that the next pandemic is foreseeable and that it is therefore time to act. The group called on politicians to respond immediately to the underlying causes of the pandemic with a view to preventing a second COVID wave and the emergence of a new pandemic. ${ }^{47}$ In order to achieve these goals, policy should act systemically, taking into account our needs as well as the relationships between people and with all living organisms. ${ }^{48}$

The research group's call resonates with what global research leaders are calling for ever since COVID19 broke out: problematic human-animal interactions such as those in Wuhan should be restricted or prohibited, the clearing of rainforests and the invasion of animal territory by humans should be stopped, and nature should not be destroyed but regenerated ${ }^{49}$ Pandemics are just one facet of larger, global changes. Equally worrying, according to the 120 -strong research group from Central Europe, is the massive extinction of species caused by changes in the natural environment, loss of habitat, depletion of resources, widespread air, water and soil pollution, and climate change. Humanity today is confronted with the consequences, "résultant de ses choix économiques et politiques." ${ }^{50}$ So it is economic and political decisions that we ourselves have made that have led us into this impasse.

The demand that we ought to rethink our relations with animals also applies to farmed animals. In an open letter from 2017, more than 200 scientists urged the Director-General of the World Health Organization (WHO) to recognize and address factory farming as a public health challenge. ${ }^{51}$ Science should devote its energies to documenting and publishing the damage that animal agriculture has done to the health of humans, animals, and the planet. The WHO must play its part, in particular by publicly acknowledging the damage that industrial farming causes to global health. Specifically, the next Director-General "should take necessary steps to limit the expansion of industrial animal farming and encourage dietary recommendations that reduce meat consumption." 52

\section{Pandemics: Global Origins, Global Action}

As we discuss these issues, it is important to stress that measures taken to reorient and reconstruct human-animal relations must be geared toward global change. Distinctions between "The West and the Rest" and the "Global North/Global South" must be questioned and critically evaluated. Particularly in the advent of the Corona crisis, stakeholders repeatedly referred to the Coronavirus as the "Chinese virus" or the "Wuhan virus." Donald Trump, for example, crossed out the word "Corona" in his notes for a press conference at the

\footnotetext{
Livestock Production. USDA Economic Research Service, Economic Research Report (2015), 200.

${ }^{43}$ WALSH, F., Superbugs to Kill „More than Cancer” by 2050. BBC News, 11 December 2014.

${ }^{44}$ As was the case in Germany: Deutscher Bundestag Drucksache 17/12051, 17. Wahlperiode 03. 01. 2013, Zugeleitet mit Schreiben des Bundesministeriums des Innern vom 21. Dezember 2012 gemäß $§ 18$ Absatz 1 und 2 des Gesetzes über den Zivilschutz und die Katastrophenhilfe des Bundes. Unterrichtung durch die Bundesregierung, Bericht zur Risikoanalyse im Bevölkerungsschutz 2012.

${ }^{45}$ In addition, almost two thirds of human infectious diseases are caused by pathogens that are shared with wild or domestic animals, i.e. zoonoses: KARESH ET AL., supra note 37.

${ }^{46}$ COLLECTIF DE 120 SCIENTIFIQUES, La prochaine pandémie est prévisible, il est temps de prendre au sérieux la crise écologique. Le Temps, 5 May 2020.

${ }^{47}$ Ibid.

${ }^{48}$ Ibid.

${ }^{49}$ For many, see BRULLIARD, K., The Next Pandemic Is Already Coming, Unless Humans Change How We Interact with Wildlife, Scientists Say. The Washington Post, 3 April 2020.

${ }^{50}$ COLLECTIF DE 120 SCIENTIFIQUES, supra note 46.

${ }^{51}$ WEATHERS, S. - HERMANNS, S., Open Letter: Why WHO Should Address Industrial Animal Farming. GRAIN, 25 May 2017.

${ }^{52}$ Ibid.
} 
White house in mid-March, and replaced it with "Chinese." 53 This terminology is ruthless and irresponsible considering how many people were discriminated against or even attacked as a result. ${ }^{54}$ It also contradicts the best practices for naming diseases, as defined by the WHO in $2015 .{ }^{55}$

To call COVID-19, which has spread worldwide, a "Chinese virus" is also absurd. Pathogens do not respect national borders; they are "not Spanish or Chinese." ${ }^{56}$ What is more important, however, is the fact that these very same dynamics happens "at home." Some of the deadliest viruses emerged from European and North American chicken and pig factories. These include the Spanish flu (one of the deadliest (bird) flus, which in 1918 affected one third of the world population), ${ }^{57}$ the swine flu (also known as "new flu", which in 2009 infected around $20 \%$ of the world's population), ${ }^{58}$ as well as several strains of bird flu and BSE (Bovine Spongiform Encephalopathy). ${ }^{59}$ Just like in Wuhan, tens of thousands of animals live crammed in a very small space - genetically standardized, immunocompromised, and drugged. Like COVID-19, these new viruses are spreading rapidly thanks to global production and supply chains and high levels of mobility of the industry and among the population. There is also a problematic intersection here: Slaughterhouses that had to remain open during the Corona crisis have literally become Corona hotspots. Be it Smithfield plants in Sioux Falls, Tyson facilities in Iowa, or Tönnies factories in Germany: The percentage of people infected with the virus continuously fluctuated between 40 and $60 \% .{ }^{60}$ So, human suffering and oppression and animal suffering and oppression often go hand in hand; in fact, they are so interconnected that they mutually reinforce each other. ${ }^{61}$

\section{Pandemics Can Be Prevented: Our Relations with Animals Will Be Decisive}

In light of these developments, we have two options for dealing with the current crisis: Either we do not change our individual and collective behaviour and accept pandemics as "our constant companions" going forward. In that case, however, we must be prepared to accept its consequences on health policy and the economy; and - more importantly - we must be prepared to be held accountable for the immense suffering that we thereby cause.

This, however, is not the only route to go. A second possibility is to view the current crisis as an opportunity: Here and now we have the chance to tackle the Corona crisis proactively through government regulation, corporate action, and changes in individual behaviour. What these steps must look like and what the precise measures will be, must be democratically determined, ${ }^{62}$ informed by the highest scientific

\footnotetext{
${ }^{53}$ BOTSFORD, J., Tweet on Twitter. Twitter, 19 March 2020. Webpage:

https://twitter.com/jabinbotsford/status/1240701140141879298 [Retrieved 7 December 2020].

${ }^{54}$ On 1 February 2020, for example, a man in Los Angeles said that Chinese people were "disgusting" and addressed his comments to a Thai-American woman. One day later in New York, an Asian woman wearing a face mask was attacked by a man who called her a "sick b*": CHIU, A., Trump Has no Qualms about Calling Coronavirus The 'Chinese Virus.' That's a Dangerous Attitude, Experts Say. The Washington Post, 20 March 2020. Not to mention the disrespectful conversation between Jesse Watters and Dana Perino on Fox News: BARAGONA, J., Fox News Host Claims Chinese People Eating 'Raw Bats' to Blame for Coronavirus. Daily Beast, 2 March 2020. This behavior also causes long-term damage: WEBEL, M., Calling COVID-19 a 'Chinese virus' Is Wrong and Dangerous - The Pandemic Is Global. The Conversation, 25 March 2020.

${ }^{55}$ The WHO gave up associations of places with a disease, such as in the case of MERS: World Health Organization, World Health Organization Best Practices for the Naming of New Human Infectious Diseases, May 2015. Webpage: https://apps.who.int/iris/bitstream/handle/10665/163636/WHO_HSE_FOS_15.1_eng.pdf?sequence=1 [Retrieved 7 December 2020]. Such a recommendation was also made in the case of COVID-19: World Health Organization, WHO Director-General's Remarks at the Media Briefing on 2019-nCoV, 11 February 2020.

${ }^{56}$ FOER, J.S. - GROSS, A.S., We Have to Wake Up: Factory Farms Are Breeding Grounds for Pandemics. The Guardian, 20 April 2020.

57 TAUBENBERGER, J.K., The Origin and Virulence of the 1918 "Spanish” Influenza Virus. Proc. Am. Philos. Soc., 150/1 (2006), 86-112.

${ }^{58}$ ROSS, R., Study Puts Global 2009 H1N1 Infection Rate at 11\% to 21\%. Center for Infectious Disease Research and Policy, 8 August 2011.

${ }^{59}$ WALLACE, supra note 37.

${ }^{60}$ Sioux Falls, S.D. the site of the Smithfield plant, which produces about $5 \%$ of the pork in the U.S., was one of the largest Corona hot spots in the US. The Tyson facility in Perry, Iowa, has already had 730 Corona cases, which accounts for nearly $60 \%$ of its workforce. At another Tyson facility in Waterloo, Iowa, there were 1,031 reported cases among approximately 2,800 employees: FOER, J.S., The End of Meat Is Here. New York Times, 21 May 2020. Similarly, in May 2020 in an abattoir in the German state of Baden-Württemberg, almost a quarter of the workforce of about 1,100 employees were tested positive for the virus: Schweizer Bauer, 80 Corona-Fälle in Schlachtbetrieb. 12 May 2020.

${ }^{61}$ See esp. KIM, C.J., Dangerous Crossings: Race, Species, and Nature in a Multicultural Age (Cambridge 2015).

62 These relations can of course be sketched by academia, proposals fleshed out, and benefits and downsides anticipated, but the decision ultimately lies in the hands of the demos. Whether and how animals should also be part of the demos is increasingly examined by animal studies scholars. For example, in "When Animals Speak," Eva Meijer, provides fascinating, real-world examples of animals communicating and acting in political ways and encourages us to rethink our relations with other animals, to the extent that their voices should be taken into account as the starting point for a new interspecies democracy: MEIJER, E., When Animals Speak: Toward
} 
standards. By no means does this paper claim to have the answers available to sketch which legal, social, political, and economic structures need to be changed and how this should be done. However, what is clear is that in the debate about necessary changes and transformations, human-animal relationships will play a significant role. It is not only bats that have interest in not being treated the same way as before. The Corona crisis has made it clear that we, too, have an interest in rethinking our relationship with the bats and with animals, more generally. But how should this be done? What role should animals play in world so heavily determined, indeed, governed by humans? Should the interests of animals be considered? How so? And should this be done for our sake or for the sake of the animals?

In animal ethics and animal studies, more broadly, scholars have been debating the "right way to treat animals" for decades. Starting in the 1980s, first-generation animal ethicists like Peter Singer have advocated for the better treatment of animals, which, depending on the country, led, for example, to the abolition of tethering, larger cages, or an opportunity for animals to access more space and exercise. ${ }^{63}$ Abolitionism, which was decisively influenced by the US-American professor Gary Francione, criticizes this: Aspirations to improve animal husbandry only legitimize animal husbandry; thereby, we accept that animals can routinely be used, confined, and killed, and this, in turn, hinders significant progress for animals. ${ }^{64}$ Abolitionism instead demands that all sentient beings should have the fundamental right not to be treated as property of others, and therefore generally rejects any and all uses of animals. One critical demand that flows from this view of justice is that all relationships between humans and animals be severed: humans must live amongst humans, animals must live amongst animals, and any form of contact or interaction must be avoided, resulting in what Acampora calls "species apartheid." ${ }^{55}$ Since contact with animals is critical in leading to the emergence of infectious zoonotic diseases, ${ }^{66}$ a precautionary approach would seem to require that we end any and all relations with animals to avoid the possibility of future pandemics. Pandemics thus seem strengthen the call for abolitionism.

Insofar as wild animals are concerned, this might indeed be true. ${ }^{67}$ However, concerning domesticated animals, things are more complex and require a more nuanced evaluation. Mainstream demands of abolitionism do not lead abolitionists to advocate for the peaceful coexistence of humans and domesticated animals - even assuming we lived separated from each other and maintained no contact. They argue that animals that have been bred for human purposes find themselves in a world so thoroughly dominated by humans, either directly (e.g., through interventions or by occupying land) or indirectly (e.g., through anthropogenic climate change), that there is no way of avoiding closeness and contact between us. We are inevitably prejudiced against animals and have a history of acting in our own interests, therefore, according to Francione, domesticated animals should gradually become extinct. ${ }^{68}$

This is where "the third-generation of animal ethics" comes in, which Sue Donaldson and Will Kymlicka heralded with their book Zoopolis. ${ }^{69}$ They criticize that the end of the exploitation of animals must necessarily lead to the end of all our relationships with animals, and accuse abolitionism of "extinctionism." 70 Past injustices are not remedied by eliminating their victims. If we were to do this, we'd only reinforce the original injustice, and thereby create new forms of injustice. Our goal must not be to abolish our relationships with animals, but to transform unjust relationships into more just ones. ${ }^{71}$ On this basis, Donaldson and Kymlicka argue that domesticated animals must be recognized as members of our society. As such, they have the right to be here, to live their lives as they see fit, to be adequately protected and cared for, and to be considered in the determination of the common good. ${ }^{72}$

What does this mean for animals currently living in farmed conditions? First of all, in agreement with some of the demands of abolitionism, breeding animals for farming purposes and keeping them to satisfy human interests (such as culinary pleasure) would not be allowed anymore. Second, in disagreement with abolitionism, we cannot unilaterally determine that domesticated animals must die out - even if this seems to

\footnotetext{
An Interspecies Democracy (New York 2019).

${ }^{63}$ SINGER, P., Animal Liberation: A New Ethics for Our Treatment of Animals (New York 1975).

${ }^{64}$ This dispute is sometimes referred to as the "animal welfare vs. animal rights" debate, sometimes as the "reform vs. revolution" debate: FRANCIONE, G.L. - GARNER, R., The Animal Rights Debate: Abolition Or Regulation? (New York 2010).

${ }^{65}$ ACAMPORA, R., Oikos and Domus: On Constructive Co-Habitation with Other Creatures. Philosophy \& Geography, 7 (2005), 219-235.

${ }^{66}$ See above, section "On Pandemics and their Emergence," and esp. FN 20.

${ }^{67}$ More on this below in this section.

${ }^{68}$ FRANCIONE, G.L., Animal Rights and Domesticated Nonhumans. Animal Rights: The Abolitionist Approach. 10 January 2007.

${ }^{69}$ DONALDSON, S. - KYMLICKA, W., Zoopolis: A Political Theory of Animal Rights (Oxford 2011).

${ }^{70} \mathrm{Id}$, at $78-79,147$.

${ }^{71} \mathrm{Id}$, at $80-81$.

${ }^{72} \mathrm{Id}$, at $73 \mathrm{ff}$.
} 
be (at least on the face) the most efficient way to reduce and prevent zoonoses - because doing so is inherently unjust to animals and morally impermissible. Doing domesticated animals justice requires acknowledging that they deserve their own place in this world and are part of an interspecies society that they have a right to be part of (if they so wish) and co-determine. Chances are high that they would not choose to live by the thousands in cramped conditions, as in conditions of factory farming. It is instead likely that they would choose to live in smaller groups - with or without humans -, occupy more space, explore their environments and move around, be able to eat healthier feed, experience fewer stressors, nurture their own relations, and hence not be reliant on antibiotics. ${ }^{73}$ With this, the conditions for the emergence and transmission of a new virus are practically eradicated. ${ }^{74}$ Working toward a just interspecies society with domesticated animals, as sketched in Zoopolis, is therefore epidemiologically sound and more just.

Wild animals, on the other hand, can organise themselves and form their own community, as Donaldson and Kymlicka argue. As such, wild animals enjoy sovereignty rights. Their relationship to us is something akin to relations between nations, and the principles governing this relation are thus something akin to "international law between the species." 75 From this follows, according to Donaldson and Kymlicka, that wild animals enjoy territorial rights; human intervention is generally prohibited; indirect harm, caused, for example, by environmental pollution or anthropogenic climate change, must be compensated. ${ }^{76}$ If we followed these proposals, notably by respecting the habitat of wild animals as sovereign territories, we would be in a much better position to prevent future zoonotic diseases.

\section{Towards “Animal Agency” and Joint Decision-Making}

Clearly, following through on these demands will necessitate a paradigm change. Going forward, the question of what (if any) relations we should maintain with animals, however, should not be unilaterally determined by us. Today, we are socially and culturally accustomed to ignore animals, to stigmatize them as "dumb," and consider them as being "controlled by their genes." 77 The majority of human-animal interactions today occur between domesticated animals used for agricultural purposes and people who ensure processes that serve purely human interests, such as rapid slaughter, for example. In these processes, the animals themselves, their desires, intentions and life plans do not matter. Animals who refuse to accept these processes by resisting and making use of their voice - verbally or non-verbally - are not heard; indeed, they are regularly silenced. ${ }^{78}$ And without law and politics making sure these voices are heard, the prospects for change are slim. ${ }^{79}$

Recognising that animals can and want to exercise agency - in our personal relationships with them, but also on a political level - is an important step toward re-constituting our relationships with them. ${ }^{80}$ Animals have their own voice, they act autonomously and usually express their likes and dislikes quite clearly. Think, for example, of the singing, chirping, screaming, mooing, running, hiding, defying, turning their backs, defending themselves, standing up for others, and many other ways in which animals exercise "embodied" communication. ${ }^{81}$ We must learn to recognize these voices instead of patronizing animals and making

\footnotetext{
${ }^{73}$ This behavior can be anticipated, to some extent, by studying how animals organize themselves and their relations with humans in sanctuary settings. See below FN 82.

${ }^{74}$ See above, section „Be it Domesticated Animals or Wild Animals: The Crux Lies in how We Treat Them.“

${ }^{75}$ DONALDSON, S., Standpunkt: Zoopolis - Grundzüge einer Theorie der Tierrechte. Bundeszentrale für politische Bildung (BPB), 28 February 2018.

${ }^{76} \mathrm{Id}$, at $156 \mathrm{ff}$.

${ }^{77}$ CORMAN, L., The Ventriloquist's Burden: Animal Advocacy and the Problem of Speaking for Others. In Animal Subjects 2.0 (Waterloo 2016) 473-51.

${ }^{78}$ For a comprehensive analysis of various forms of animal resistance, see HRIBAL, J., Fear of the Animal Planet: The Hidden History of Animal Resistance (New York 2010); GILLESPIE, K., Nonhuman Animal Resistance and the Improperties of Live Property. In Animals, Biopolitics, Law: Lively Legalities (London and New York 2016) 117-132; WADIWEL, D., The War Against Animals (Leiden 2015).

${ }^{79}$ MEIJER, E., When Animals Speak: Toward An Interspecies Democracy (New York 2019).

${ }^{80}$ DONALDSON, S., - KYMLICKA, W., Between Wildness and Domestication: Rethinking Categories and Boundaries in Response to Animal Agency. In Animal Ethics in the Age of Humans: Blurring Boundaries in Human-Animal Relationships (Cham 2016), 225242; MEIJER, E., Interspecies Democracies. In Animal Ethics in the Age of Humans (Cham 2016) 53-72.

${ }^{81}$ Greenhough and Roe argue for embodied decision-making in animals as regards the question of whether they can consent, but the authors generally provide useful examples of the tremendous repertoire of communicative skills that animals possess: GREENHOUGH, B., - ROE, E., Ethics, Space, and Somatic Sensibilities: Comparing Relationships between Scientific Researchers and their Human and Animal Subjects. Environment and Planning D: Society and Space 29 (2011) 47-66. See generally MEIJER, E., Animal Languages: The Secret Conversations of the Living World (London 2020). And in the context of labour: BLATTNER, C.E., Animal Labour: Toward a Prohibition of Forced Labour and A Right to Freely Choose One's Work. In Animal Labour: A New Frontier of Interspecies Justice? (Oxford 2020) 91-115.
} 
sweeping decisions for and about them.

What rights for animals and more just relationships with them could or should look like in concrete terms is being studied by a growing number of scientists from various disciplines. ${ }^{82}$ One thing is clear though: up until today, we have spent far too little energy and time thinking about ways to make relationships with animals more just and fair. And we have never asked ourselves the very difficult questions, such as: What exactly do animals want? Are just, short- or long-term relationships between us possible? What types of human-animal relationships are acceptable to them? How can we make sure that we are not using the animals' interests as an excuse to advance our own, but that instead we are truly working toward relationships that empower us both?

\section{Conclusion}

As we were painfully reminded by COVID-19, the interests and well-being of animals and humans are not in competition with each other, but in mutual dependence, and can therefore only be addressed and solved in tandem. If we acknowledge these interrelationships and if we are prepared to fundamentally rethink and change how we approach and interact with animals, much can be achieved. The Corona crisis signifies a moment of rupture where new socio-political configurations can emerge. This momentum of change should be seized to begin working to establish a Zoopolis - a shared interspecies society between humans and domesticated animals, and the recognition of wild animals as sovereigns. A future without pandemics is only one positive aspect of this effort to reconsider, reframe, and repurpose human-animal relationships. Interspecies justice is the other.

\section{Bibliography}

- ACAMPORA, R., Oikos and Domus: On Constructive Co-Habitation with Other Creatures. Philosophy \& Geography, 7 (2005), 219-235.

- AFELT, A. - DEVAUX, C. - SERRA-COBO, J. - FRUTOS, R., Bats, Bat-Borne Viruses, and Environmental Changes. IntechOpen, (2018), 113-132. DOI: 10.5772/intechopen.74377.

- BARAgonA, J., Fox News Host Claims Chinese People Eating 'Raw Bats' to Blame for Coronavirus. Daily Beast, 2 March 2020.

- BEER, G. - DOHERR, M.G. - BÄHLER, C. - MEYLAN, M., Antibiotikaeinsatz in der Schweizer Kälbermast. SAT / ASMV, 1 (2015), 55-57. DOI 10.17236/sat00005.

- BLATTNER, C.E. - DONALDSON, S. - WILCOX, R., Animal Agency in Community: A Political Multispecies Ethnography of VINE Sanctuary. Politics \& Animals, 6 (2020), 1-22.

- BLATTNER, C.E., Animal Labour: Toward a Prohibition of Forced Labour and A Right to Freely Choose One's Work. In Animal Labour: A New Frontier of Interspecies Justice? (Oxford 2020) 91115.

- BOISSAY, F. - RUNGCHAROENKITKUL, P., Macroeconomic Effects of COVID-19: An Early Review. BIS-Bulletin, No. 7, 17 April 2020.

- BOSKIN, M.J., How Does the COVID Recession Compare? World Economic Forum, 28 August 2020.

- BRUlliARD, K., The Next Pandemic Is Already Coming, Unless Humans Change How We Interact with Wildlife, Scientists Say. The Washington Post, 3 April 2020.

- CAVE, D., New Zealand Election Delayed Amid New Coronavirus Outbreak. New York Times, 17 April 2020.

- CHIU, A., Trump Has no Qualms about Calling Coronavirus The 'Chinese Virus.' That's a Dangerous Attitude, Experts Say. The Washington Post, 20 March 2020.

- COLLECTIF DE 120 SCIENTIFIQUES, La prochaine pandémie est prévisible, il est temps de prendre au sérieux la crise écologique. Le Temps, 5 May 2020.

- CORMAN, L., The Ventriloquist's Burden: Animal Advocacy and the Problem of Speaking for Others. In Animal Subjects 2.0 (Waterloo 2016) 473-512.

- DAILYMOTION, Hundreds of Bats Burned in Indonesia in Bid to Prevent Coronavirus Spread. 1 March 2020.

\footnotetext{
${ }^{82}$ See e.g., BlATTNER, C.E. - DONALDSON, S. - WILCOX, R., Animal Agency in Community: A Political Multispecies Ethnography of VINE Sanctuary. Politics \& Animals, 6 (2020), 1-22, who innovatively use multispecies ethnography and feminist accounts of the self as a springboard, to investigate animal agency in a sanctuary for formerly farmed animals, considering how a careful exploration of dimensions of agency in this setting can inform ideas of interspecies ethics and politics. 
- DALTON, J., Coronavirus: Exterminating Bats Blamed for Spreading Covid-19 Would Increase Risk of Further Diseases, Warn Experts. The Independent, 19 April 2020.

- DONALDSON, S. - KYMLICKA, W., Zoopolis: A Political Theory of Animal Rights (Oxford 2011).

- DONALDSON, S., - KYMLICKA, W., Between Wildness and Domestication: Rethinking Categories and Boundaries in Response to Animal Agency. In Animal Ethics in the Age of Humans: Blurring Boundaries in Human-Animal Relationships (Cham 2016), 225-242.

- DONALDSON, S., Standpunkt: Zoopolis - Grundzüge einer Theorie der Tierrechte. Bundeszentrale für politische Bildung (BPB), 28 February 2018.

- DREXLER, J.F. - CORMAN, V.M. - DROSTEN, C., Ecology, Evolution and Classification of Bat Coronaviruses in the Aftermath of SARS. Antiviral Research, 101 (2014), 45-56.

- DRUCKENFIELD, J., Antibiotic Resistance Due to Modern Agricultural Practices: An Ethical Perspective. Journal of Agricultural and Environmental Ethics, 26 (2013), 333-350.

- EVANS, M., Plight of the Pangolin: Once Coveted, Now Feared because of Coronavirus. CNN, 14 June 2020.

- FLINDERS, M., Coronavirus Blame Games - Who really Benefits? The Conservation, 3 April 2020.

- FOER, J.S. - GROSS, A.S., We Have to Wake Up: Factory Farms Are Breeding Grounds for Pandemics. The Guardian, 20 April 2020.

- FOER, J.S., The End of Meat Is Here. New York Times, 21 May 2020.

- FRANCIONE, G.L. - GARNER, R., The Animal Rights Debate: Abolition Or Regulation? (New York 2010).

- FRANCIONE, G.L., Animal Rights and Domesticated Nonhumans. Animal Rights: The Abolitionist Approach. 10 January 2007.

- GILLESPIE, K., Nonhuman Animal Resistance and the Improperties of Live Property. In Animals, Biopolitics, Law: Lively Legalities (London and New York 2016) 117-132.

- GREENHOUGH, B., - ROE, E., Ethics, Space, and Somatic Sensibilities: Comparing Relationships between Scientific Researchers and their Human and Animal Subjects. Environment and Planning D: Society and Space 29 (2011) 47-66.

- GROSS, O., Emergency Powers in the Time of Coronavirus... and Beyond. Just Security, 8 May 2020.

- HITCHENS, P. - Johnson, C., Don't Blame the Pangolin (Or Any Other Animals) for COVID-19. Pursuit, 8 April 2020.

- HRIBAL, J., Fear of the Animal Planet: The Hidden History of Animal Resistance (New York 2010).

- IRMER, J., Jagd auf Fledermäuse und Flughunde: Die Sündenböcke der Pandemie bezahlen mit dem Leben. NZZ am Sonntag, 4. April 2020.

- JABR, F., How Humanity Unleashed a Flood of New Diseases. The New York Times, 25 June 2020.

- KAPAN, D.D. - BENNETT, S.N. - ELLIS, B.N. - FOX, J. - LEWIS, N.D. - SPENCER, J.H., SAKSENA, S. - WILCOX B.A., Avian Influenza (H5N1) and the Evolutionary and Social Ecology of Infectious Disease Emergence. EcoHealth, 3 (2006), 187-194.

- KAPNER, S., Coronavirus Has Shut Stores, and Retailers Are Running Out of Time. The Wall Street Journal, 8 April 2020.

- KARESH, W.B. - DOBSON, A. - LLOYD-SMITH, J.O. - LUBROTH, J. - DIXON, M.A. BENNETT, M. ALDRICH, S.- HARRINGTON, T. - FORMENTY, P. - LOH, E.H. MACHALABA, C.C. - JASON, M. - HEYMANN, D.L., The Ecology of Zoonoses: Natural and Unnatural Histories. The Lancet, 380 (2012), 1936-1945.

- KIM, C.J., Dangerous Crossings: Race, Species, and Nature in a Multicultural Age (Cambridge 2015).

- MASON, J. - FINELli, M., Brave New Farm? In In Defense of Animals: The Second Wave (Malden MA and Oxford, UK, 2006) 104-122.

- MASON, J. - SINGER, P., Animal Factories (New York 1980, revised 1990).

- MAThenY, G. - LEAHY, C., Farm-Animal Welfare, Legislation and Trade. L. \& Contemp. Probs., 70 (2007), 325.

- MEIJER, E., Animal Languages: The Secret Conversations of the Living World (London 2020).

- MEIJER, E., Interspecies Democracies. In Animal Ethics in the Age of Humans (Cham 2016) 5372 . 
- MEIJER, E., When Animals Speak: Toward An Interspecies Democracy (New York 2019).

- MUKERJI, N. - MANNINO, A., Covid-19: Was in der Krise zählt (Stuttgart 2020).

- NEWMAN, S.H. - FIELD, H. - EPSTEIN, J.- DE JONG, C. (eds), Investigating the Role of Bats in Emerging Zoonoses: Balancing Ecology, Conservation and Public Health Interest. FAO Animal Production and Health Manual No. 12. Rome (2011). Webpage: http://www.fao.org/3/a-i2407e.pdf [Retrieved 7 December 2020].

- O'SHEA, T.J. - CRYAN, P.M. - ANDREW, A. - CUNNINGHAM, A.A. - FOOKS, A.R. HAYMAN, D.T.S. - LUIS, A.D. - PEEL, A.J. - LOWRIGHT, R.K. - WOOD, J.L.N., Bat Flight and Zoonotic Viruses. Emerging Infectious Diseases, 20 (2014) 741-745.

- PILling, D., Coronavirus and the Collapse of Global Public Health. Financial Times, 12 March 2020.

- PROBYN-RAPSEY, F.- DONALDSON, S. - IOANNIDES, G. - LEA, T. - MARSH, K., A Sustainable Campus: The Sydney Declaration on Interspecies Sustainability. Animal Studies Journal, 5/1 (2015), 110-151.

- ROSS, R., Study Puts Global 2009 H1N1 Infection Rate at $11 \%$ to 21\%. Center for Infectious Disease Research and Policy, 8 August 2011.

- SAlCEDO, A. - YAR, S. - CHERELUS, G., Coronavirus Travel Restrictions, Across the Globe. The New York Times, 16 July 2020.

- SINGER, P., Animal Liberation: A New Ethics for Our Treatment of Animals (New York 1975).

- SLOTNIK, D., Coronavirus Demolished Air Travel around the Globe. Business Insider, 22 April 2020.

- TAUBEnBERGER, J.K., The Origin and Virulence of the 1918 "Spanish" Influenza Virus. Proc. Am. Philos. Soc., 150/1 (2006), 86-112.

- URALDE, J., Congress' Failure to Enact Animal Welfare Legislation for the Rearing of Farm Animals: What Is Truly at Stake? U. Miami Bus. L. Rev., 9 (2001), 193.

- VAN BOECKEL, T.P. - BROWER, C. - GILBERT, M. - GRENFELL, B.T. - LEVIN, S.A. ROBINSON, T.P. - TEILLANT, A. - LAXMINARAYAN, R., Global Trends in Antimicrobial Use in Food Animals, PNAS, 112/18 (2015), 5649-5654.

- WADIWEL, D., The War Against Animals (Leiden 2015).

- WALLACE, R., Big Farms Make Big Flu: Dispatches on Infectious Disease, Agribusiness, and the Nature of Science (New York 2016).

- WALLACE, R.G., Breeding Influenza: The Political Virology of Offshore Farming. Antipode, 41/5 (2009), 916-951.

- WALSH, F., Superbugs to Kill „More than Cancer” by 2050. BBC News, 11 December 2014.

- WEATHERS, S. - HERMANNS, S., Open Letter: Why WHO Should Address Industrial Animal Farming. GRAIN, 25 May 2017.

- WEBEL, M., Calling COVID-19 a 'Chinese virus' Is Wrong and Dangerous - The Pandemic Is Global. The Conversation, 25 March 2020.

\section{Legal Sources \\ Legislations}

- Verordnung über Höchstbestände in der Fleisch- und Eierproduktion (Höchstbestandesverordnung, HBV). SR 916.344. 23 October 2013. Art. 2 para. 1 (Switz.).

\section{Court Cases \\ Other Sources}

- BJØRNSKOV, C. - VOIGT, S., This Time is Different? - On the Use of Emergency Measures During the Corona Pandemic. ILE Working Paper Series No. 36, University of Hamburg, Institute of Law and Economics (ILE), Hamburg.

- BOTSFORD, J., Tweet on Twitter. Twitter, 19 March 2020. Webpage: https://twitter.com/jabinbotsford/status/1240701140141879298 [Retrieved 7 December 2020].

- Deutscher Bundestag Drucksache 17/12051, 17. Wahlperiode 03. 01. 2013, Zugeleitet mit Schreiben des Bundesministeriums des Innern vom 21. Dezember 2012 gemäß $§ 18$ Absatz 1 und 2 des Gesetzes über den Zivilschutz und die Katastrophenhilfe des Bundes. Unterrichtung durch die 
Bundesregierung, Bericht zur Risikoanalyse im Bevölkerungsschutz 2012.

- European Commission, Communication from the Commission to the Council and the European Parliament on Animal Welfare Legislation on Farmed Animals in Third Countries and the Implications for the EU. COM(2002) 626 final (18 November 2002).

- European Parliamentary Research Service EPRS, Coronavirus and the World of Work. Webpage: https://www.europarl.europa.eu/RegData/etudes/BRIE/2020/649395/EPRS_BRI(2020)649395_E N.pdf [Retrieved 7 December 2020].

- Farm Animal Investment Risk and Return (FAIRR), An Industry Infected: Animal Agriculture in a post-COVID World (2020). Webpage: https://www.fairr.org/article/industry-infected/ [Retrieved 7 December 2020].

- INTER-PARLIAMENTARY UNION, Country Compilation of Parliamentary Responses to the Pandemic. Webpage: https://www.ipu.org/country-compilation-parliamentary-responses-pandemic [Retrieved 7 December 2020].

- Schweizer Bauer, 80 Corona-Fälle in Schlachtbetrieb. 12 May 2020.

- SNEERINGER, S. - MACDONALD, J. - KEY, N. - MCBRIDE, W. - MATHEWS, K., Economics of Antibiotic Use in US Livestock Production. USDA Economic Research Service, Economic Research Report (2015).

- Tier im Fokus (TIF), Arme Schweine. Webpage: https://arme-schweine.ch/ [Retrieved 7 December 2020].

- World Animal Protection (WAP), Animal Protection Index. Webpage: https://api.worldanimalprotection.org/ [Retrieved 7 December 2020].

- World Animal Protection (WAP), Switzerland. Webpage: https://api.worldanimalprotection.org/country/switzerland [Retrieved 7 December 2020].

- World Economic Forum, Global Risks Report. 14th ed. 2019, 46. Webpage: http://www3.weforum.org/docs/WEF_Global_Risks_Report_2019.pdf [Retrieved 7 December 2020].

- World Health Organization, WHO Director-General's Remarks at the Media Briefing on 2019nCoV, 11 February 2020.

- World Health Organization, World Health Organization Best Practices for the Naming of New Human Infectious Diseases, May 2015.2 Webpage: https://apps.who.int/iris/bitstream/handle/10665/163636/WHO_HSE_FOS_15.1_eng.pdf?sequenc $\mathrm{e}=1$ [Retrieved 7 December 2020]. 